Tropical Journal of Pharmaceutical Research July 2017; 16 (7): 1529-1536

ISSN: $1596-5996$ (print); 1596-9827 (electronic)

(C) Pharmacotherapy Group, Faculty of Pharmacy, University of Benin, Benin City, 300001 Nigeria.

All rights reserved.

Available online at http://www.tjpr.org

Original Research Article

http://dx.doi.org/10.4314/tjpr.v16i7.10

\title{
Capecitabine treatment of HCT-15 colon cancer cells induces apoptosis via mitochondrial pathway
}

\author{
Mingli $\mathrm{Li}^{1 \star}$, Na Zhang ${ }^{2}$ and Mingxuan $\mathrm{Li}^{3}$ \\ ${ }^{1}$ Biology and Medicine, ${ }^{2}$ Pharmaceutics, Shandong University, Shandong 250100, ${ }^{3}$ Department of Nursing, Affiliated Hospital of \\ Jining Medical University, Jining, Shandong 272029, China
}

*For correspondence: Email: limingli689@hotmail.com; Tel/Fax: 0086-531-88565657

\begin{abstract}
Purpose: To investigate the effect of capecitabine on apoptosis induction in HCT-15 colon carcinoma cells and investigate the underlying mechanism.

Methods: Phase-contrast microscopy was used for the examination of morphological changes while flow cytometry was employed for the analysis of cell cycle distribution, induction of apoptosis, reactive oxygen species (ROS) production and expression of caspases. Western blot assay was used for the analysis of expression level of apoptosis-related and cell cycle regulatory proteins.

Results: Capecitabine treatment caused changes in the morphological appearance of HCT-15 cells after $48 \mathrm{~h}$. The viability of HCT-15 cells was reduced to $23 \%$ on treatment with capecitabine (5 $\mu \mathrm{M})$ compared to $98 \%$ in the control cultures. Incubation with capecitabine increased the population of HCT15 cells in GO/G1 phase to $56.43 \%$ compared to $41.67 \%$ in the control. Capecitabine treatment of HCT-15 cells caused condensation of DNA and induced apoptosis in a concentration-dependent manner. At $5 \mu \mathrm{M}$ concentration of capecitabine, apoptosis was induced in $45.74 \%$ of the cells. Incubation of HCT-15 cells with capecitabine for $48 \mathrm{~h}$ led to a significant increase in the production of ROS. Translocation of Endo $G$ and AIF from mitochondria to the nuclei increased significantly $(p<$ 0.005) on treatment with $5 \mu \mathrm{M}$ capecitabine. Capecitabine treatment also reduced the expression of cyclin E and Cdc25c and promoted the level of caspases, Bax, AIF, Endo G, p21, PARP and p-p53. The expression level of Bcl-2 decreased in HCT-15 cells on incubation with $5 \mu \mathrm{M}$ concentration of capecitabine.

Conclusion: Capecitabine treatment causes inhibition of colon cancer growth via the mitochondrial pathway of apoptosis. Thus, capecitabine may have therapeutic application in colon carcinoma treatment.
\end{abstract}

Keywords: Capecitabine, 5-Fluorouracil, Translocation, Colon cancer, Colitis, Apoptosis

Tropical Journal of Pharmaceutical Research is indexed by Science Citation Index (SciSearch), Scopus, International Pharmaceutical Abstract, Chemical Abstracts, Embase, Index Copernicus, EBSCO, African Index Medicus, JournalSeek, Journal Citation Reports/Science Edition, Directory of Open Access Journals (DOAJ), African Journal Online, Bioline International, Open-J-Gate and Pharmacy Abstracts

\section{INTRODUCTION}

Colorectal cancer is globally considered as the most common cancer found in people of all age groups and alone constitutes $10 \%$ of cancerrelated deaths [1]. It is a malignant neoplasm originating from the lining of the colon. Colorectal cancer metastasizes to various distant organs and its most common target is the liver. One type of colon cancer is colitis-associated cancer which is characterized by the onset of inflammatory bowel disease of ulcerative colitis [2]. It has been reported that $15 \%$ of patients with colorectal cancer show liver metastases [3]. Among various types of solid tumors only in patients with colorectal cancer can the survival term be increased by surgical extraction of distant metastases from various organs such as liver 
and lungs [4]. The survival of the unresectable metastases of colorectal cancer patients can be increased by treatment with systemic chemotherapy [5].

Cell apoptosis is a programmed mechanism for death of unwanted cells which can take place via intrinsic or extrinsic pathways [6,7]. Various ligands interact with surface receptors (tumor necrosis factor) and death receptors leading to cell apoptosis through extrinsic pathway $[7,8]$. However, cellular processes like oxidative stress, DNA damage and cytotoxic agents lead to apoptosis through the intrinsic pathway [7].

In caspase dependent method of apoptosis various proteins such as components of $\mathrm{Bcl}-2$ class are involved in the maintenance of activation of caspases $[9,10]$. Treatment of cancer by induction of cell apoptosis using chemotherapeutic agents is one of the best strategies. Therefore, screening of new molecules for the development of treatment strategy can improve the clinical outcome for patients with colorectal cancer.

Capecitabine is a modified derivative of fluoropyrimidine aimed to selectively transfer 5fluorouracil into tumor cell. The method of administration of capecitabine is very simple and comfortable. In gastric cancer treatment capecitabine is used either singly or in combination with other chemotherapeutic agents [11]. Administration of higher doses of capecitabine to patients of gastric cancer cause side effects such as diarrhea, lymphopenia, nausea etc. However, lower doses have been found to be effective.

In the present study effect of capecitabine on viability and apoptosis induction in human colon cancer cells was investigated. The study demonstrated that capecitabine treatment at lower doses causes inhibition of colon cancer growth via mitochondrial pathway of apoptosis. Thus capecitabine can be a very good candidate for the treatment of colon cancer.

\section{EXPERIMENTAL}

\section{Chemicals and reagents}

Capecitabine was purchased from Roche Pharmaceutical Company (Nutley, NJ, USA) and its solution was freshly prepared at the time of use in dimethylsulfoxide (DMSO). Propidium iodide, Triton $\mathrm{X}-100$, Tris- $\mathrm{HCl}$ and trypan blue were supplied by Sigma Chemical Co (St Louis, MO, USA).

\section{Cell culture and cell viability assay}

HCT-15 human colon cancer cell line purchased from Food Industry Research and Development Institute (Hsinchu, Taiwan). The cell cultureswere grown in RPMI-1640 (Gibco BRL) containing 10 $\%$ fetal bovine serum (FBS, HyClone). The medium was supplemented with $2 \mathrm{mM}$ glutamine (Sigma-Aldrich) and antibiotics such as penicillin $(100 \mathrm{U} / \mathrm{mL})$ and streptomycin $(100 \mu \mathrm{g} / \mathrm{mL})$. The cells were cultured in an incubator at $37{ }^{\circ} \mathrm{C}$ temperature under $5 \% \mathrm{CO}_{2}$ atmosphere.

\section{Determination of cell morphology and viability}

HCT-15 cells at $4 \times 10^{4}$ cells per well density were distributed in 12-well plates and incubated for $24 \mathrm{~h}$. The cells were then subjected to $48 \mathrm{~h}$ incubation with $0,1,2,3,4$ and $5 \mu \mathrm{M}$ doses of capecitabine under an atmosphere of $5 \% \mathrm{CO}_{2}$ at $37{ }^{\circ} \mathrm{C}$. After incubation phase-contrast microscope was used to examine the cells for changes in morphology. For analysis of viability the cells were collected after incubation with capecitabine, centrifuged and then subjected to PI $(5 \mu \mathrm{g} / \mathrm{mL})$ staining before analysis using flow cytometry (Becton-Dickinson, San Jose, CA, USA).

\section{Analysis of apoptosis}

HCT-15 cells after incubation with or without capecitabine for $48 \mathrm{~h}$ were collected and trypsinized. The cells were then washed twice with phosphate-buffered saline and subsequently resuspended at a density of $2 \times 10^{6}$ cells per $\mathrm{ml}$ in binding buffer.

The cells were then treated with $5 \mu \mathrm{L}$ each of annexin-V-fluorescein isothiocyanate and propidium iodide $(\mathrm{PI})$ and subjected to incubation for $15 \mathrm{~min}$ at room temperature. FACScalibur Flow Cytometer (BD Biosciences, San Jose, CA, USA) was used for the analysis of cell apoptosis.

\section{Analysis of cell cycle}

HCT-15 cells after incubation with or without capecitabine for $48 \mathrm{~h}$ were collected and trypsinized. The cells were collected and then fixed overnight at $4{ }^{\circ} \mathrm{C}$ using $70 \%$ ethyl alcohol. The cells were re-suspended in the dark at $37^{\circ} \mathrm{C}$ for half an hour in PBS supplemented with PI (40 $\mu \mathrm{g} / \mathrm{mL})$ and RNase $(0.1 \mathrm{mg} / \mathrm{mL})$ Triton X-100 $(0.1 \%)$. Flow cytometer connected with an argon 
ion laser was used for analysis of the cells at a wavelength of $490 \mathrm{~nm}$.

\section{Determination of reactive oxygen species (ROS) production}

HCT- 15 cells at density of $2 \times 10^{6}$ cells per mL were incubated with indicated doses of capecitabine for $48 \mathrm{~h}$. The cells were collected and treated with $10 \mu \mathrm{M}$ solution of 2, 7dichlorodihydrofluorescein diacetate (DCFH-DA) for half an hour at $37{ }^{\circ} \mathrm{C}$. After incubation the cells were analyzed using flow cytometry for production of reactive oxygen species.

\section{Western blot analysis}

HCT-15 cells after incubation with capecitabine for $48 \mathrm{~h}$ under the appropriate conditions were collected and washed two times with ice-cold PBS. The cells were then treated with lysis buffer [40 mM Tris ( $\mathrm{pH} 8.0)$, sodium chloride $(120 \mathrm{mM})$, NP-40 $(0.5 \%)$, sodium or thovanadate $(0.1 \mathrm{mM})$, aprotinin $(2 \mu \mathrm{g} / \mathrm{mL})$, leupeptin $(2 \mu \mathrm{g} / \mathrm{mL})$ and phenymethylsulfonyl fluoride $(100 \mu \mathrm{g} / \mathrm{mL})]$ to get the lysate. From the lysate supernatant was collected to determine the concentration of proteins (Pierce, Rockford, IL).

Denaturation of extracted proteins was performed with sample buffer [Tris- $\mathrm{HCl}(0.5 \mathrm{M})$, pH $6.8,4 \%$ SDS, glycerol (20\%), bromophenol blue $(0.1 \%), \beta$-mercaptoethanol (10\%)] for 10 min at $100{ }^{\circ} \mathrm{C}$. Isolation of the proteins was achieved on 6-15\% SDS-PAGE and the proteins were subsequently transferred onto PVDF membranes.

The non-specific sites in the membranes were blocked for $1 \mathrm{~h}$ with $5 \%$ non-fat dry milk in Trisbuffered saline with Tween-20 buffer at room temperature. Membrane incubation with primary antibodies was performed overnight. Following incubation $4 \mathrm{X}$ TBS-T buffer was used for washing of the membrane for $15 \mathrm{~min}$ followed by $1 \mathrm{~h}$ incubation with horseradish peroxidaseconjugated anti-rabbit or anti-mouse immunoglobin (Santa Cruz Biotechnology Inc., Santa Cruz, CA).

Thereafter, $1 \times$ TBS-T buffer was used for washing the membrane for $15 \mathrm{~min}$. The complex format on interaction of antigen with antibody was analyzed using enhanced chemiluminescence (ECL) detection system (GE Healthcare Biosciences, Pittsburgh, PA). The primary antibodies against caspase- $9,-3,-8$, Bax, Bal-2, Endo G, AIF and PARP were obtained from R\&D Systems (Minneapolis, USA) whereas those against Cdc25c, cyclin E, p- p53and p21were obtained from Santa Cruz Biotechnology (CA).

\section{Confocal laser scanning microscopy for protein translocation}

HCT-15cells were distributed at a density of $2 x$ $10^{5}$ cells per well onto 4 -well chamber slides and cultured. The cells were incubated without or with the indicated concentration of capecitabine for 48 h. Cells on the slides were fixed for over $20 \mathrm{~min}$ using $4 \%$ formaldehyde in PBS. The cells were permeabilized by treatment with Triton- $X 100$ $(0.3 \%)$ in PBS for $1 \mathrm{~h}$. The non-specific sites blocked with $2 \%$ BSA. Staining of the cells was performed overnight by incubation with primary antibodies against AIF and Endo G (1: 100 dilution). The stained cells were incubated with secondary antibody (FITC conjugated goat antimouse IgG at $1: 100$ dilution) and subsequently subjected to DNA staining using mitotracker. Leica TCS SP2 confocal spectral microscope was used for obtaining the photomicrographs.

\section{DAPI staining}

HCT-15cellsat a density of $2 \times 10^{5}$ cells per $\mathrm{ml}$ were incubated with or without capecitabine for $48 \mathrm{~h}$. After incubation the cells were subjected to DAPI $\quad$ 4, 6-diamidino-2-phenylindole dihydrochloride) staining. Then fluorescence microscope was used for examination of the stained cells.

\section{Statistical analysis}

The data are expressed as mean \pm standard deviation (SD). Student's t-test was used for the analysis of the differences among the groups; $p$ $<0.05$ was considered statistically significant. Microsoft Excel 2007 was used for the analysis

\section{RESULTS}

\section{Capecitabine alters the morphology and reduces viability of HCT-15 cells}

Phase-contrast microscopy showed changes in the morphological appearance of HCT-15 cells on incubation with capecitabine. Changes in the cell morphology were dependent on the concentration of capecitabine. Flow cytometry revealed that capecitabine treatment significantly $(p<0.005)$ reduced the viability of HCT-15 cells. At $5 \mu \mathrm{M}$ concentration of capecitabine the viability of HCT-15 cells was reduced to $23 \%$ compared to $98 \%$ in the control cultures (Figure 1B). 

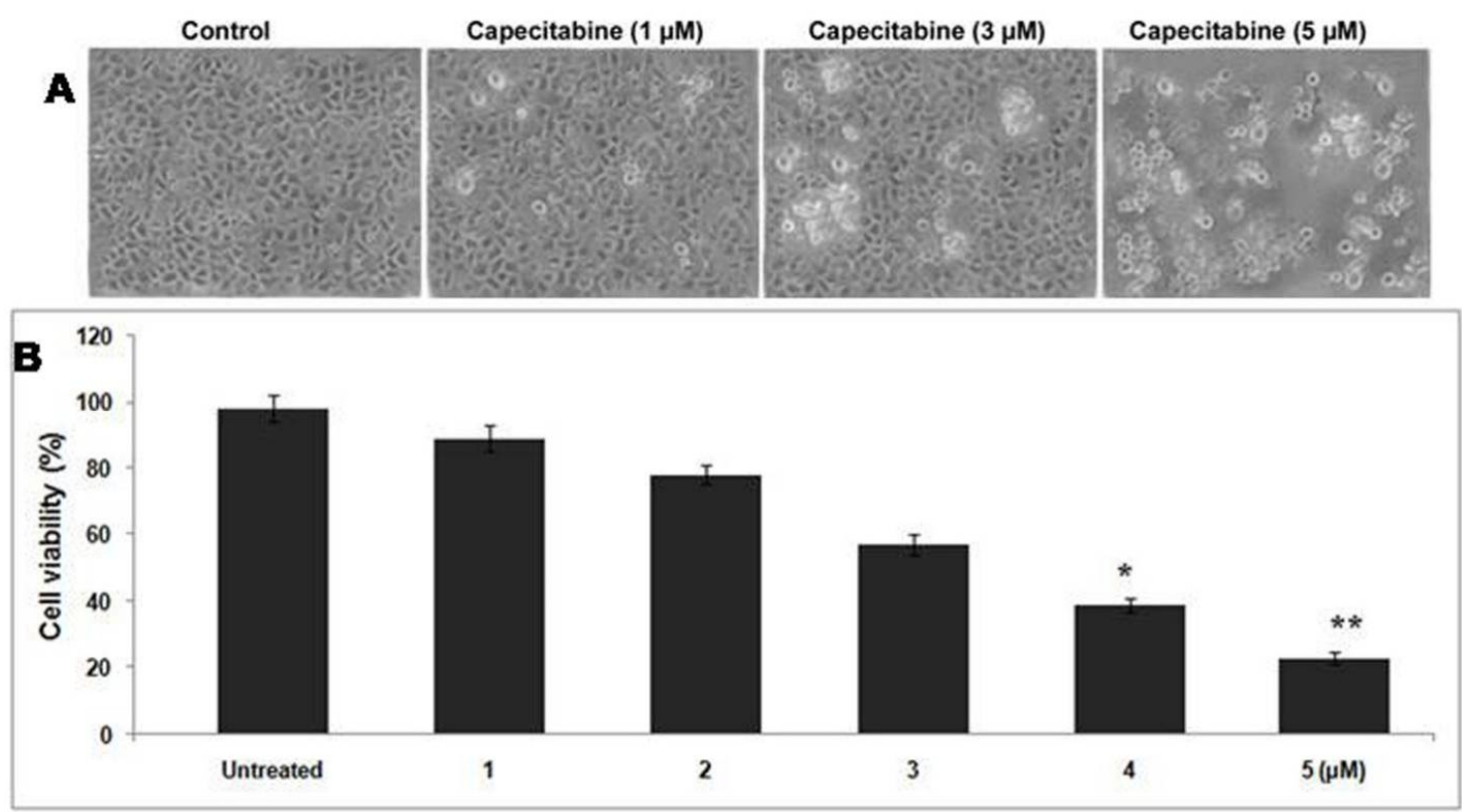

Figure 1: Capecitabine alters the morphology and reduces the viability of HCT-15 cells. Incubation of the cells with 1, 2, 3, 4 and $5 \mu$ Mconcentrations of capecitabine was carried out for $48 \mathrm{~h}$. (A) Changes in cell morphology was examined using phase-contrast microscopy after $48 \mathrm{~h}$ of treatment. (B) The cell viability was analyzed using flow cytometry; $p<0.05$ compared to the control cells

\section{Capecitabine increases the population of} HCT-15 cells in G0/G1 phase

Incubation of HCT-15 cells with capecitabine for $48 \mathrm{~h}$ increased the population of cells in G0/G1 phase in a concentration dependent manner with subsequent reduction in S-phase (Figure 2). Capecitabine treatment at $5 \mu \mathrm{M}$ concentration
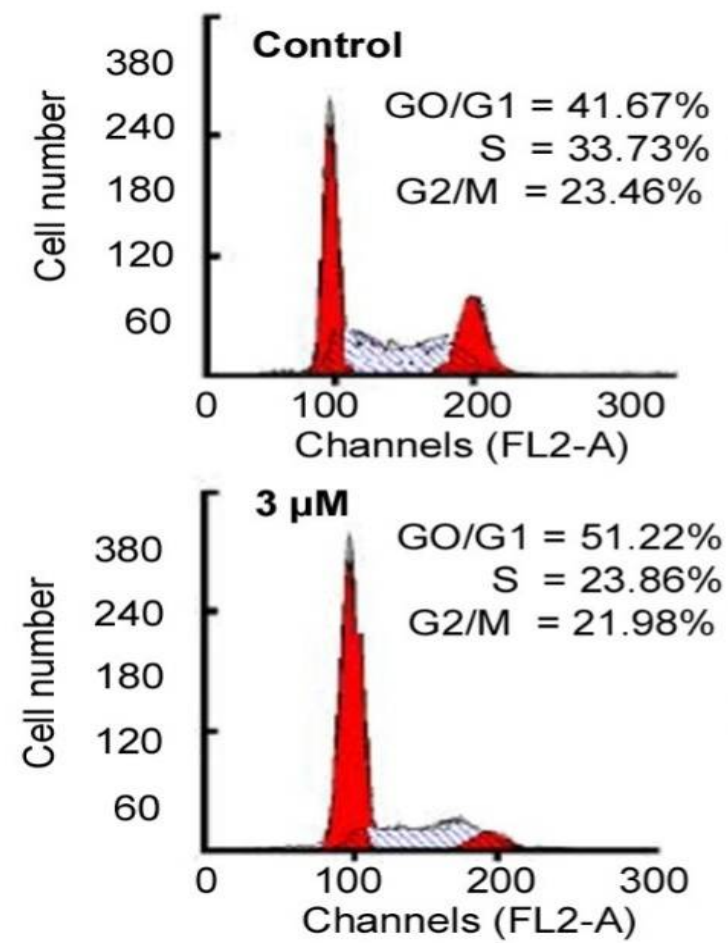

increased the population of HCT-15 cells in G0/G1 phase to $56.43 \%$ compared to $41.67 \%$ in the control. The population of cells in S-phase was decreased to $19.89 \%$ in capecitabine treated cultures compared to $33.73 \%$ in the control cultures.
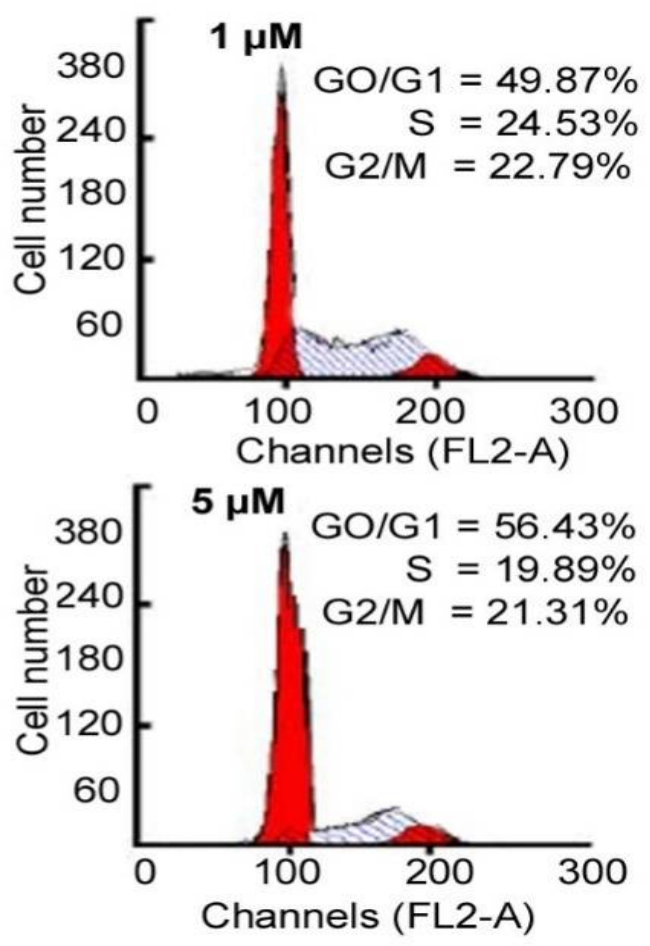

Figure 2: Capecitabine arrests cell cycle of HCT-15 cells. Cell incubation for $48 \mathrm{~h}$ with 1, 2, 3, 4and $5 \mu \mathrm{M}$ of capecitabine was followed by analysis using flow cytometry; ${ }^{*} p<0.05$ in comparison with control 
Capecitabine treatment of HCT-15 cells causes induction of apoptosis

The results from DAPI and Annexin V staining revealed that capecitabine treatment of HCT-15 cells caused condensation of DNA and induced apoptosis in concentration dependent manner (Figure 3). At $5 \mu \mathrm{M}$ concentration of capecitabine apoptosis was induced in $45.74 \%$ of HCT-15 cells after $48 \mathrm{~h}$ compared to $3.39 \%$ in the control.

Capecitabine increases reactive oxygen species production (ROS) in HCT-15 cells

Incubation of HCT-15 cells with various concentrations of capecitabine for $48 \mathrm{~h}$ led to increase in the production of ROS in concentration dependent manner. The production of ROS was significantly higher at 5 $\mu \mathrm{M}$ concentration of capecitabine after $48 \mathrm{~h}$ (Figure 4).

\section{Capecitabine increases translocation of Endo $G$ and AIF from mitochondria in colon carcinoma cells}

Incubation of HCT-15 cellsfor $48 \mathrm{~h}$ with capecitabine increased the translocation of Endo $\mathrm{G}$ and AIF from mitochondria to the nuclei. The expression level of Endo $\mathrm{G}$ and AIF proteins was significantly $(p<0.005)$ higher in HCT-15 cells at $5 \mu \mathrm{M}$ capecitabine (Figure 5).
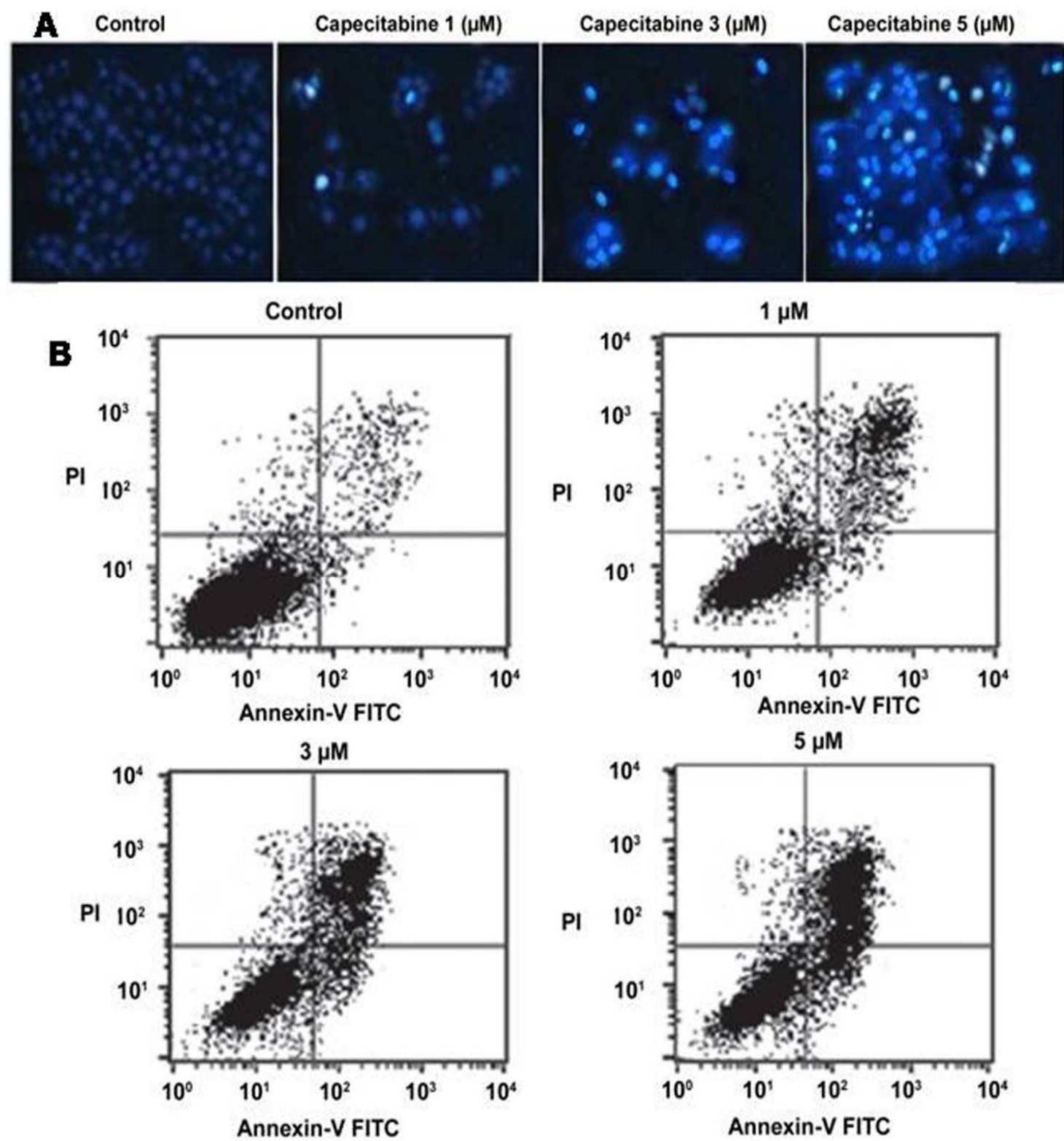

Figure 3: Capecitabine induces apoptosis in HCT-15 cells. The cells after incubation for 1, 2, 3, 4 and $5 \mu \mathrm{M}$ concentration of capecitabine were collected and stained with DAPI and Annexin $\mathrm{V}$ for analysis of DNA damage and induction of apoptosis; ${ }^{*} p<0.05$ compared to control 


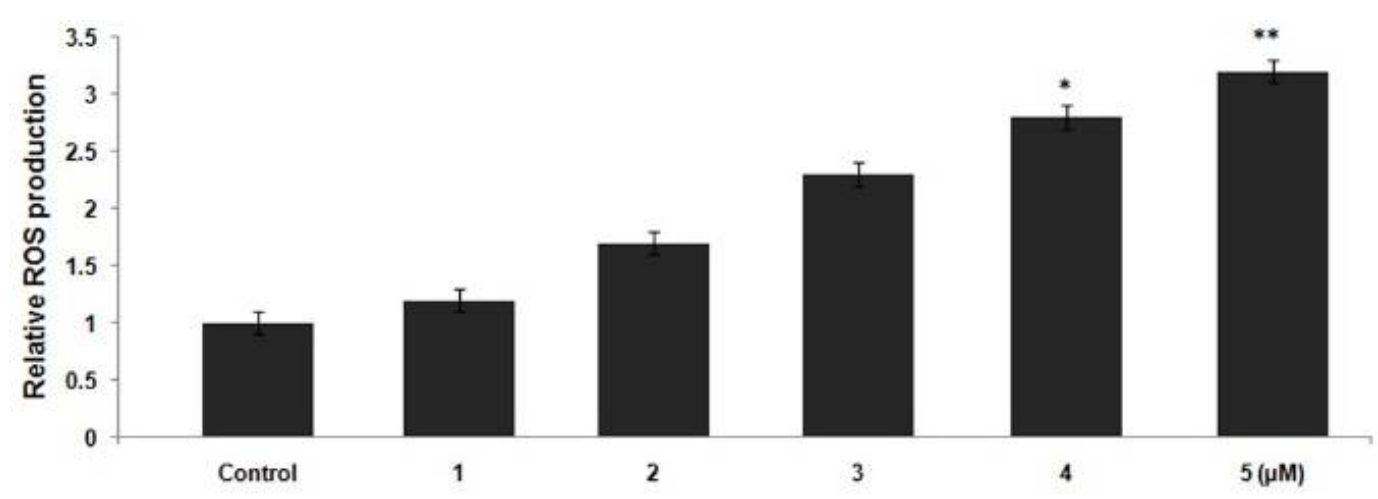

Figure 4: Capecitabine increases reactive oxygen species production (ROS) in HCT-15 cells. The cells were incubated with 1, 2, 3, 4 and $5 \mu \mathrm{M}$ concentration of capecitabine for $48 \mathrm{~h}$ and then the production of ROS was analysed. DCFH-DA stain was used for flow cytometric examination; $p<0.05$ compared to control

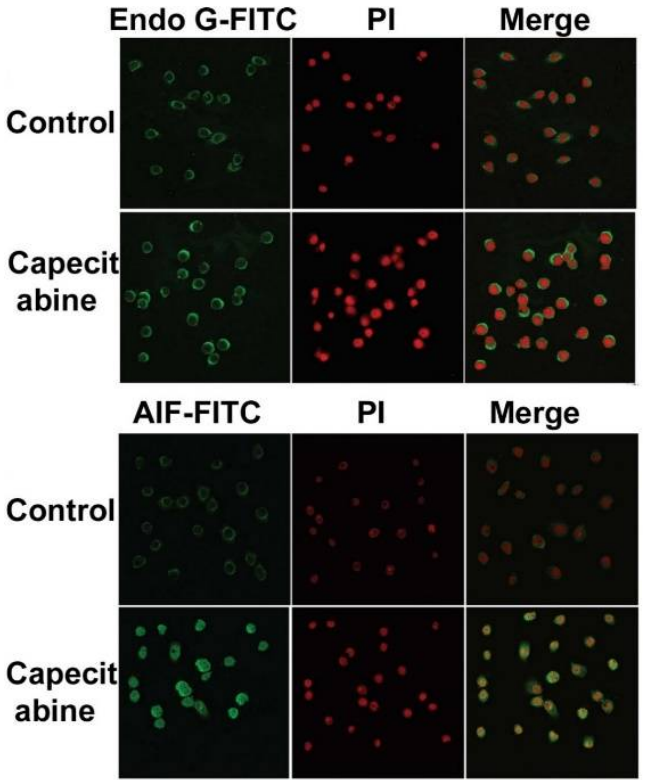

Figure 5: Capecitabine increases Endo G and AIF translocation from mitochondria in colon carcinoma cells. The cell incubation with $5 \mu \mathrm{M}$ concentration of capecitabine was performed for $48 \mathrm{~h}$ and then the expression of Endo $\mathrm{G}$ and AIF was analyzed using confocal laser microscopy
Capecitabine alters expression of cell cycle and apoptosis-related proteins in HCT-15 cells

Western blot analysis showed that incubation of HCT-15 cells with various concentrations of capecitabine influenced the expression of p21, pp53, cyclin E, Cdc25c, Bax and cleavagecaspases after $48 \mathrm{~h}$. HCT-15 cells on incubation with $5 \mu \mathrm{M}$ doses of capecitabine reduced the expression of cyclin $\mathrm{E}$ and $\mathrm{Cdc} 25 \mathrm{c}$ and promoted the level of caspases-8, -3, Bax, AIF, Endo G, PARP, p21 and p-p53. The expression level of $\mathrm{Bcl}-2$ was decreased in HCT-15 cells on incubation with $5 \mu \mathrm{M}$ capecitabine for $48 \mathrm{~h}$ (Figure 6).

\section{DISCUSSION}

The current study was aimed to investigate the effect of various concentrations of capecitabine on HCT-15 human colon cancer cells. The results showed a decrease in viability and increase in apoptosis of HCT-15 cells via mitochondrial pathway on exposure to capecitabine.

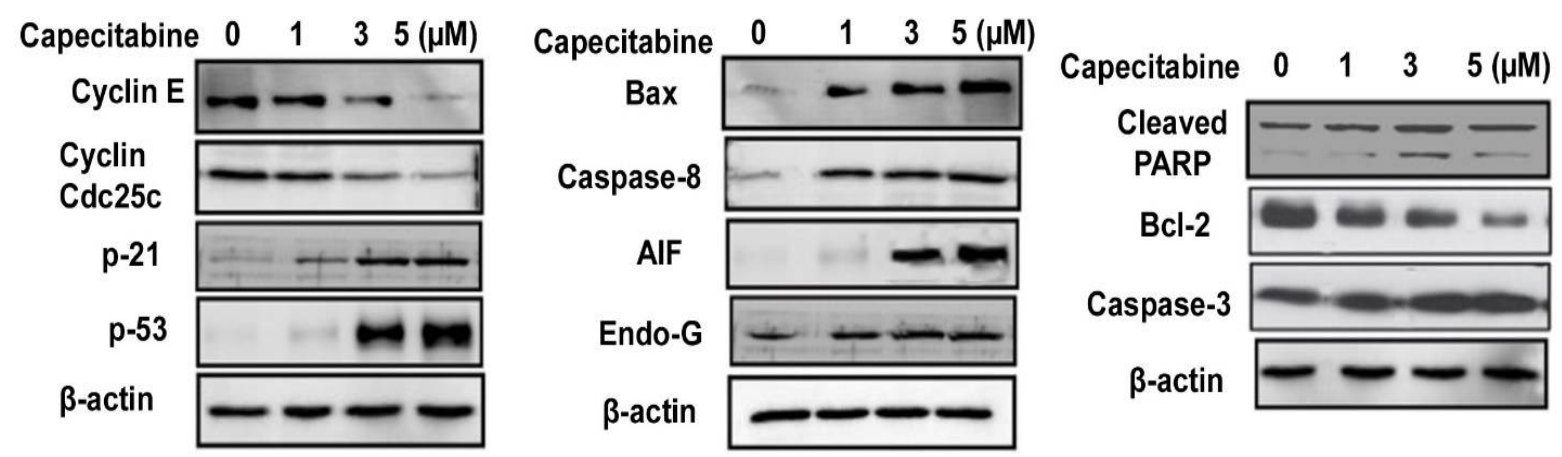

Figure 6: Capecitabine changes the expression ofproteins involved in regulation of the cell cycle and apoptosis in HCT-15 cells. Incubation of the cells with 1, 2, 3, 4 and $5 \mu \mathrm{M}$ capecitabine was performed for $48 \mathrm{~h}$ followed by analysis using western blot. The expression was compared with $\beta$-actin as loading control 
Incubation of HCT-15 cells with capecitabine led to reduction in viability to a marked level based on the concentration used. Progression of cell cycle through various phases is regulated by different kinases which play important role in the action of cdc/cdk kinases [12]. Cyclins D/cdk on activation regulate progression of $\mathrm{G} 1, \mathrm{E} / \mathrm{cdk} 2$ activation G1/S, A/cdk2 activation $S$ and cyclin $A$ and cyclin $B / c d k 1$ regulate progression of $\mathrm{G} 2 / \mathrm{M}$ phases $[13,14]$. Investigation of the underlying mechanism of capecitabine induced reduction in HCT-15 cell viability revealed arrest of cell cycle in $\mathrm{G} 0 / \mathrm{G} 1$ phase. TheG0/G1 phase arrest was further confirmed by increase in p53 and p21 expression and decrease in Cdc25c and cyclin E level in capecitabine treated cells. Up-regulation of Bax expression causes increase in the mitochondrial membrane permeability which results in activation of caspases and subsequently cell apoptosis [15-17]. In HCT-15 cells incubation with capecitabine induced apoptosis significantly and increased the activation of caspases.

The mitochondrial translocation of proteins AIF and Endo $G$ was increased significantly on incubation of HCT-15 cells with capecitabine. The level of pro-apoptotic protein (Bax) expression was promoted in the cells incubated with capecitabine. On the other hand, the antiapoptotic protein $\mathrm{Bcl}-2$ expression was decreased. It is reported that increase in the generation of cellular reactive oxygen species induces cell cycle arrest and apoptosis [18, 19]. Results from the current study showed that incubation of HCT-15 cells with capecitabine led to increase in the production of reactive oxygen species. There are reports that increase in the expression level of p21 in the cells is related with the JNK pathway activation [20]. The results from the present study showed that capecitabine treatment of HCT-15 cells significantly increased the expression of $\mathrm{p} 21$.

\section{CONCLUSION}

Capecitabine treatment causes inhibition of colon cancer growth via the mitochondrial pathway of apotposis. Thus, capecitabine may be useful for the treatment of colon cancer.

\section{DECLARATIONS}

\section{Acknowledgement}

None declared

\section{Conflict of Interest}

No conflict of interest associated with this work.

\section{Contribution of Authors}

The authors declare that this work was done by the authors named in this article and all liabilities pertaining to claims relating to the content of this article will be borne by them.

\section{Open Access}

This is an Open Access article that uses a funding model which does not charge readers or their institutions for access and distributed under the terms of the Creative Commons Attribution License (http://creativecommons.org/licenses/by/ 4.0) and the Budapest Open Access Initiative (http://www.budapestopenaccessinitiative.org/rea d), which permit unrestricted use, distribution, and reproduction in any medium, provided the original work is properly credited.

\section{REFERENCES}

1. Ferlay J, Shin HR, Bray F, Forman D, Mathers $C$, Parkin $D M$. Estimates of worldwide burden of cancer in 2008: GLOBOCAN 2008. Int J Cancer 2010; 127: 2893-2917.

2. Fujimoto K, Hosotani R, Doi R, Wada M, Lee JU, Koshiba $T$, Miyamoto $Y$, Tsuji S, Nakajima S, Imamura $M$ : Induction of cell-cycle arrest and apoptosis by a novel retinobenzoic-acid derivative, TAC-101, in human pancreatic-cancer cells. Int J Cancer 1999; 81: 637-644.

3. Manfredi S, Lepage C, Hatem C, Coatmeur O, Faivre J, Bouvier AM. Epidemiology and management of liver metastases from colorectal cancer. Ann Surg 2006; 244: 254-259.

4. Hughes KS, Rosenstein RB and Songhorabodi S: Resection of the liver for colorectal carcinoma metastases. A multi-institutional study of long-term survivors. Dis Colon Rectum 1988; 31: 1-4.

5. Venook A. Critical evaluation of current treatments in metastatic colorectal cancer. Oncologist 2005; 10: 250261.

6. Degterev A, Boyce M, Yuan J: A decade of caspases. Oncogene 2003; 22: 8543-8567.

7. Ziegler DS, Kung AL: Therapeutic targeting of apoptosis pathways in cancer. Curr Opin Oncol 2008; 20: 97-103.

8. Klein S, McCormick F, Levitzki A: Killing time for cancer cells. Nat Rev Cancer 2005; 5: 573-580.

9. Adams JM, Cory S: The Bcl-2 protein family: Arbiters of cell survival. Science 1998; 281: 1322-1326.

10. Antonsson B, Martinou JC: The Bcl-2 protein family. Exp Cell Res 2000; 256: 50-57.

11. Tham CK, Choo SP, Poon DY: Capecitabine with radiation is an effective adjuvant therapy in gastric cancers. World J Gastroenterol 2010; 16: 3709-3715. 
12. Hartwell LH, Weinert TA: Checkpoints: Controls that ensure the order of cell cycle events. Science 1989; 246: 629-634.

13. Malumbres M, Barbacid M: To cycle or not to cycle: $A$ critical decision in cancer. Nat Rev Cancer 2001; 1: 222231.

14. Jackman M, Lindon C, Nigg EA, Pines J: Active cyclin B1Cdk1 first appears on centrosomes in prophase. Nat Cell Biol 2003; 5: 143-148.

15. Adams JM, Cory S: The Bcl-2 protein family: Arbiters of cell survival. Science 1998; 281: 1322-1326.

16. Antonsson B, Martinou JC: The Bcl-2 protein family. Exp Cell Res 256: 50-57, 2000.
17. Salvesen GS, Dixit VM: Caspases: Intracellular signaling by proteolysis. Cell 1997; 91: 443-446.

18. Rauh R, Kahl S, Boechzelt H, Bauer R, Kaina B, Efferth $T$ : Molecular biology of cantharidin in cancer cells. Chin Med 2007; 2: 8.

19. Ozben T: Oxidative stress and apoptosis: Impact on cancer therapy. J Pharm Sci 2007; 96: 2181-2196.

20. Xiao L, Eto M, Kazanietz MG: ROCK mediates phorbol ester-induced apoptosis in prostate cancer cells via p21Cip1 upregulation and JNK. J Biol Chem 2009; 284: 29365-29375. 